\title{
Influence of Er:YAG Laser Irradiation on Apical Sealing of Four Different Sealers
}

\author{
Isabel MELLO ${ }^{1}$ \\ Carlos Roberto Colombo ROBAZZA ${ }^{2}$ \\ João Humberto ANTONIAZZI ${ }^{1}$ \\ ${ }^{1}$ Department of Endodontics, School of Dentistry, University of São Paulo, São Paulo, SP, Brazil \\ ${ }^{2}$ Department of Endodontics, Federal University Center of Alfenas, Alfenas, MG, Brazil
}

\begin{abstract}
The sealing of the root canal system is of fundamental importance for successful endodontic treatment. To obtain an adequate apical seal, many factors must be considered such as the presence of smear layer and the sealer applied. After canal preparation, this layer must be removed because it prevents close contact between the dentinal walls and the sealing material. The goal of this study was to evaluate the sealing ability of four different sealers after smear layer removal with either 17\% EDTA-T irrigation or Er:YAG laser irradiation of 46 teeth. The canals were sealed with four different sealers: Sealapex, Ketac Endo, AH Plus and N-Rickert. The method for smear layer removal did not influence apical sealing. AH Plus and N-Rickert allowed less dye leakage when compared to Sealapex and Ketac Endo.
\end{abstract}

Key Words: Er:YAG laser, microleakage, sealers, smear layer.

\section{INTRODUCTION}

Apical sealing of the root canal system is of fundamental importance for the success of endodontic treatment. For adequate apical sealing, the presence of smear layer and the sealer to be used must be considered, among other factors.

Smear layer is a mixture of scraps of dentin, vital or decomposed organic residues, microorganisms and irrigating substances (1). It is divided into two layers: a superficial layer, weakly adhered to the subjacent layer and easy to remove, and a deeper layer, strongly adhered to the dentin and also projecting into the interior of the dentinal tubules (2). After root canal preparation, smear layer must be removed because it does not allow disinfection, it compromises intra-canal dressing diffusion and it prevents close contact between the dentinal walls and the sealing material (3). The smear layer itself may be contaminated and it could protect bacteria inside the dentinal tubules (4).

Smear layer has been studied by various authors using different methodologies and its removal is recommended, considering that no smear provides better canal sealing $(5,6)$. Removal can be accomplished with the aid of chelating agents or laser devices. The most commonly used solution is EDTA, pure or associated with detergents (7). The most efficient laser is the Er:YAG laser because it provides clean surfaces, evaporated smear layer and open dentinal tubules $(8,9)$.

Among other physico-chemical properties, the sealing ability of sealers is important. For many years, an inadequate apical seal has been considered responsible for the failure of endodontic treatment (10).

Sealers can be classified as epoxy resin-based, zinc oxide and eugenol-based, glass ionomer-based and calcium hydroxide sealers. Much research has been carried out to evaluate the sealing ability of the sealers available (11-15).

Kimura et al. (16) evaluated apical microleakage in canals sealed with gutta-percha and sealer. One half of the teeth were submitted to conventional canal preparation while the other half was prepared with Er:YAG laser. Their results showed no difference in dye penetration between the groups tested.

Because of the controversy about the sealing efficacy of different sealers in the presence or not of 
smear layer, the goal of this study was to evaluate the sealing ability of four different sealers using both methods for smear layer removal.

\section{MATERIAL AND METHODS}

Forty-six single-rooted human teeth were cleaned and hydrated. Access was made with round and endo-Z burs. The teeth were filed $1 \mathrm{~mm}$ on the side of the apex with K-files (Maillefer, Ballaigues, Switzerland) and $1 \%$ sodium hypochlorite. The canals were prepared up to \#45 file. The teeth were subsequently divided into two groups: NL (not lased) and L (lased). The canals from the NL group were irrigated with 17\% EDTA-T (EDTA + detergent), aspirated and dried with paper points. The canals from the $\mathrm{L}$ group were lased with Er:YAG laser (Kavo KEY, Biberach, Germany) - 4 Hz, $200 \mathrm{~mJ}, 2.25 \mathrm{~W}, 20 \mathrm{~s}$ (17). For lasing, a 35-like file fiber was used and helicoidal movements in a crown-apical and vice-versa direction were applied (18).

The teeth of both groups were then made externally impermeable with ethyl cyanoacrylate, not sealing the apical foramen. At the time of endodontic sealing, the teeth were once again divided into four new groups of 10 teeth each (5 $\mathrm{NL}$ and $5 \mathrm{~L}$ ), according to the sealer used: group 1: Sealapex (Kerr, Romulus, MI, USA); group 2: Ketac Endo (ESPE, Seefeld/Oberbay, Germany); group 3: AH Plus (Maillefer, Ballaigues, Switzerland); group 4: N-Rickert (Formula e Ação, São Paulo, SP, Brazil).

The sealers were manipulated according to manufacturer instructions. In all groups, the sealers were placed into the canals with the main guttapercha point surrounded by the sealer and, after adaption, accessory points were introduced also with the sealer. The excess was removed by hot instruments and cleaning was done with cotton pellets. The pulp chamber was filled with Cavit.

Three control groups (two positive and a negative one) were made to test methodological fidelity and quality.

Immediately after coronal sealing, the teeth were immersed in $0.5 \%$ methylene blue, $\mathrm{pH} 7.2$, for $48 \mathrm{~h}$ in flasks. After this period, the teeth were washed in running water to remove excess dye and dried with filter paper. The crowns of all specimens were cut and the roots were cut under cleav- age in a crown-apical direction, providing two hemisections. The sealing material was removed immediately and the specimens were evaluated with a microscope $(15 x)$ with millimeter ocular to measure dye leakage.

\section{RESULTS}

The results are summarized in Figure 1. ANOVA showed that Er:YAG laser irradiation did not influence the sealing ability of the sealers compared to EDTA-T. However, there were statistical differences among the sealers. According to Tukey's test, there was no statistical difference either between AH Plus and N-Rickert or between Sealapex and Ketac Endo. However, grouping the data, there was a statistical difference between the AH Plus and N-Rickert group and the Sealapex and Ketac Endo group, with the first group showing less dye leakage compared to the second group (Table 1).

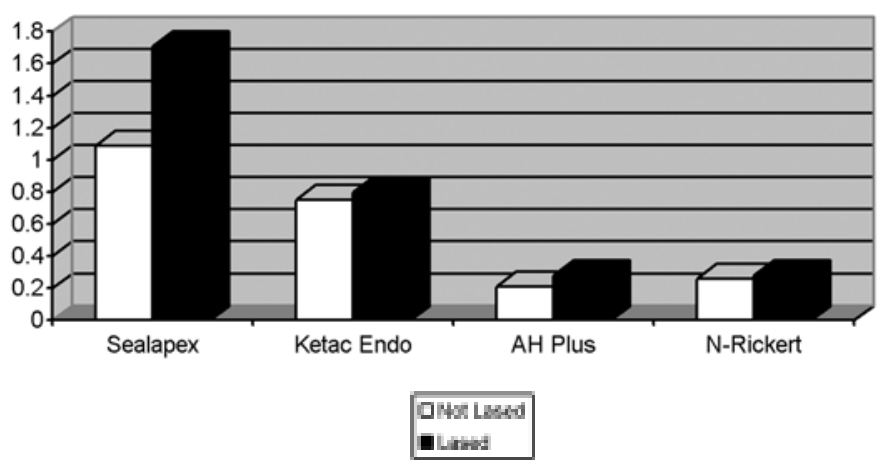

Figure 1. Means of leakage (in $\mathrm{mm}$ ) of experimental groups.

Table 1. Difference of means of sealers tested (Tukey $=0.3693)$.

\begin{tabular}{lccc}
\hline & Ketac Endo & AH Plus & N-Rickert \\
\hline Sealapex & $0.3077 n s$ & $\begin{array}{c}0.74895 s \\
\text { Sealapex }>\text { AH Plus }\end{array}$ & $\begin{array}{c}0.81605 s \\
\text { Sealapex }>\text { N-Rickert }\end{array}$ \\
Ketac Endo & - & $0.4412 s$ & $0.5083 s$ \\
& & Ketac Endo $>$ AH Plus & Ketac Endo $>$ N-Rickert \\
AH Plus & - & - & $0.0671 n s$ \\
\hline
\end{tabular}

$s=$ significant $; n s=$ not significant 


\section{DISCUSSION}

Although there is an infinity of sealers available on the market, research has demonstrated that none of them is capable of completely preventing apical leakage (11). Many works have been developed with the purpose of analyzing sealer properties, in particular, apical sealing ability $(3,6,10-15)$.

In this study, four different sealers were used with the objective of comparing the findings among them. AH Plus, an epoxy resin-based sealer, allowed low dye leakage, similar to N-Rickert, a zinc oxide + eugenol-based sealer, with the addition of delta-hydrocortisone. Both Sealapex (sealer with calcium hydroxide) and Ketac Endo (glass ionomer-based sealer) showed greater dye leakage.

Economides et al. (6) also reported better results with a resin-based sealer when compared to a calcium hydroxide-based sealer. Goldberg et al. (11) did not find differences when comparing a glass ionomer-based sealer and a zinc oxide-based sealer. Pommel et al. (15) also found the highest leakage level for the teeth sealed with the calcium hydroxide-based sealer Sealapex.

The removal of smear layer is extremely important because it causes a series of undesirable effects, i.e., obstructs dentinal tubules, shelters microorganisms and does not allow close contact between the canal walls and the sealer (1-4). EDTA has been largely employed as a resource to remove smear layer because of its calcium chelating capacity (5,7). Er:YAG laser was selected for this study because it promotes clean dentinal walls, no smear surfaces and open dentinal tubules $(8,9)$. The helicoidal movements that were employed permitted the irradiation of the entire surface without great temperature increase (18). The findings that laser irradiation did not interfere with dye penetration is in agreement with Kimura et al. (16) who reported that this laser did not interfere in apical leakage.

A perfect apical sealing that prevents the penetration of microorganisms and their products and organic fluids into the canal is the goal of canal obturation. However, further research must be developed with the purpose of finding better techniques to obtain the most effective apical sealing.

We conclude that Er:YAG laser irradiation did not interfere with the sealing ability of the sealers tested compared to EDTA-T. AH Plus and N-Rickert sealers provided a better apical sealing when compared to
Sealapex and Ketac Endo sealers.

\section{RESUMO}

O selamento do sistema de canais radiculares é de fundamental importância para o sucesso do tratamento endodôntico. Para um adequado selamento apical, devemos considerar, entre outros fatores, a presença da smear layer e o cimento obturador empregado. Após o preparo do canal, esta camada deve ser removida pois, entre outros fatores, impede contato íntimo entre a parede dentinária e o material obturador. $\mathrm{O}$ objetivo deste trabalho foi avaliar a capacidade seladora de quatro diferentes cimentos obturadores após remoção da smear layer com irrigação com EDTA-T a 17\% ou irradiação com laser Er:YAG. Os 46 dentes humanos foram instrumentados e a smear layer foi removida por irrigação com EDTA-T ou irradiação com laser Er:YAG. Os canais foram obturados com 4 diferentes cimentos obturadores: Sealapex, Ketac Endo, AH Plus e N-Rickert. O método de remoção da smear layer não interferiu no selamento apical. Quanto aos cimentos testados, o AH Plus e o N-Rickert permitiram menos infiltração do corante quando comparados aos cimentos Sealapex e Ketac Endo.

\section{REFERENCES}

1. Brannstrom M, Nyborg H. Bacterial growth and pulpar changes under inlays cemented with zinc phosphate cement and Epoxylite CBA 9080. J Prosthet Dent 1974;31:556-565.

2. Cameron JA. The synergistic relationship between ultrasound and sodium hypochlorite: a scanning electron microscope evaluation. J Endod 1987;13:541-545.

3. White RR, Goldman M, Lin PS. The influence of the smeared layer upon dentinal tubule penetration by endodontic filling materials. Part 1l. J Endod 1987;13:369-374.

4. Torabinejad M, Handysides R, Khademi AA, Bakland LK. Clinical implications of the smear layer in Endodontics: a review. Oral Surg Oral Med Oral Pathol Oral Radiol Endod 2002;94:658-666.

5. Behrend GD, Cutler CW, Gutmann JL. An in-vitro study of smear layer removal and microbial leakage along root-canal fillings. Int Endod J 1996;29:99-107.

6. Economides N, Kokorikos I, Kolokouris I, Panagiotis B, Gogos C. Comparative study of apical sealing ability of a new resinbased root canal sealer. J Endod 2004;30:403-405.

7. Hulsmann $M$, Heckendorff $M$, Lennon A. Chelating agents in root canal treatment: mode of action and indications for their use. Int Endod J 2003;36:810-830.

8. Takeda FH, Harashima T, Kimura Y, Matsumoto K. A comparative study of the removal of smear layer by three endodontic irrigants and two types of laser. Int Endod J 1999;32:32-39.

9. Takeda FH, Harashima T, Kimura Y, Matsumoto K. Comparative study about three types of laser devices. J Clin Laser Med Surg 1998; 16:117-122.

10. Dow PR, Ingle JI. Isotope determination of root canal failure. Oral Surg Oral Med Oral Pathol 1955;8:1100-1104.

11. Goldberg F, Artaza LP, de Silvio A. Apical sealing ability of a new glass ionomer root canal sealer. J Endod 1995;21:498-500.

12. Miletic I, Ribaric SP, Karlovic Z, Jukic S, Bosnjak A, Anic I. Apical leakage of five root canal sealers after one year of storage. J Endod 2002;28:431-432. 
13. Sousa-Neto MD, Passarinho-Neto JG, Carvalho-Junior JR, Cruz-Filho AM, Pecora JD, Saquy PC. Evaluation of the effect of EDTA, EGTA and CDTA on dentin adhesiveness and microleakage with different root canal sealers. Braz Dent J 2002;13:123-128.

14. Cobankara FK, Adanir N, Belli S, Pashley DH. A quantitative evaluation of apical leakage of four root canal sealers. Int Endod J 2002;35:979-984.

15. Pommel L, About I, Pashley D, Camps J. Apical leakage of four endodontic sealers. J Endod 2003;29:208-210.
16. Kimura Y, Yonaga K, Yokoyama K, Matsuoka E, Sakai K, Matsumoto K. Apical leakage of obturated canals prepared with Er:YAG laser. J Endod 2001;27:567-570.

17. Sousa-Neto MD, Marchesan MA, Pécora JD, Brugnera-Júnior A, Silva-Sousa YTC, Saquy PC. Effect of Er:YAG laser on adhesion of root canal sealers. J Endod 2002;28:185-187.

18. Gutknecht N, Kaiser F, Hassan A, Lampert F. Long-term clinical evaluation of endodontically treated teeth by Nd:YAG lasers. J Clin Laser Surg 1996;14:7-11.

Accepted January 15, 2004 